\title{
The Influence of Personality Traits on Life Satisfaction Through Work Engagement and Job Satisfaction among Academic Faculty Members
}

\author{
Marek Blatný, Petr Květon, \\ Martin Jelínek \\ Institute of Psychology, Czech Academy of \\ Sciences, Brno, Veveri 97, Czech Republic
}

\author{
Iva Šolcová, Kateřina Zábrodská, Jiří Mudrák, \\ Kateřina Machovcová \\ Institute of Psychology, Czech Academy of Sciences, \\ Praha, Hybernska 8, Czech Republic
}

\begin{abstract}
The aim of this study was to examine both direct and indirect associations of the personality traits of extraversion, neuroticism and conscientiousness with life satisfaction through work engagement and job satisfaction. The study population consisted of 2229 academics $(57.1 \%$ men) throughout Czech public universities, who completed a questionnaire comprising measures of employee personality traits (BFI-10), work engagement (Utrecht Work Engagement Scale short form), job satisfaction (job satisfaction short scale from the COPSOQ-II) and general life satisfaction (Satisfaction With Life Scale). Structural equation modeling was used to analyze the relationships. The strongest predictor of life satisfaction was neuroticism, the effect of which manifested itself through both direct and indirect pathways. Extraversion and conscientiousness had positive indirect influences on job satisfaction through work engagement, but their direct influences on job satisfaction were negative. While extraversion also had a direct influence on life satisfaction, conscientiousness did not directly influence life satisfaction.

Key words: personality traits, characteristic adaptations, life satisfaction, job satisfaction, work engagement
\end{abstract}

\section{Introduction}

Well-being has long been researched in psychology. Over the years, several influential theories explaining the nature and describing the components of this psychological construct have been created (Diener, 2000; Lyubomirsky,

Acknowledgements

The study was supported by grants No. GA17-20856S and RVO: 68081740. The study is a part of research program "Strategy AV21".

Correspondence concerning this article should be addressed to Marek Blatný, Institute of Psychology of the Czech Academy of Sciences, Veveri 97, 60200 Brno, Czech Republic. E-mail: blatny@psu.cas.cz

Received May 31, 2018
Sheldon, \& Schkade, 2005; Ryff, 2014; Seligman, 2011), and many studies have identified factors contributing to well-being. Personality traits were identified as factors significantly influencing well-being, among other characteristics. Within the five-factor model of personality, traits of neuroticism, extraversion and conscientiousness appear to be the strongest and most consistent predictors of well-being (Steel, Schmidt, \& Shultz, 2008).

In the past, research primarily addressed the relationship between personality traits and various aspects and facets of well-being. Recently, there has been increasing interest in exploring specific pathways by which personality traits influence well-being (Lent et al., 2005). Personality dispositions affect well-being not only directly, through emotions, but also indirectly 
through their influence on many other important life outcomes at the interpersonal (quality of relationships) and social institutional levels (occupational choice and performance, community involvement) (Ozer \& Benet-Martínez, 2006).

Indirect influences of personality traits on well-being can be mediated through both characteristic adaptations and domain satisfaction. Under current approaches (McAdams \& Pals, 2006; McCrae \& Costa, 1999), personality comprises two basic levels - basal tendencies, represented by personality traits, and characteristic adaptations, referring to "a wide range of motivation, socio-cognitive and developmental adaptations" that are specific to a given time, place or role (McAdams \& Pals, 2006, p. 208). Previous research has shown that variables such as self-efficacy or the use of coping strategies contribute to life satisfaction and are correlated with personality traits (Cellar, Yorke, Nelson, \& Carroll, 2004; Watson, Suls, \& Haig, 2002). Therefore, there arose a reasonable assumption that motivational and socio-cognitive variables mediate or moderate the relationship between personality dispositions and well-being, and this hypothesis was confirmed in subsequent studies (Blatný \& Šolcová, 2015).

Human life includes a series of areas in which different levels of satisfaction can be achieved. Diener, Suh, Lucas, and Smith (1999) refer to satisfaction with a given area of human life as domain satisfaction. Even satisfaction in specific life domains is influenced by personality characteristics, including both domain-specific social cognitive variables and affective and temperamental traits (Lent et al., 2005).

In our study, we focused on job satisfaction because work is one of the most important areas of adult life and because job satisfaction can significantly contribute to overall life satisfaction. We specifically examined how work engagement, a sense of energetic and effective connection with work activities that supports people in handling the demands of their job, serves as a characteristic adaptation that mediates the relationships between personality traits and job satisfaction.

\section{Life Satisfaction}

Life satisfaction is a key indicator of subjective quality of life, especially in the theory of subjective well-being (SWB) of Diener (2000), nonetheless, life satisfaction is also considered in other conceptions of well-being (Lyubomirsky et al., 2005; Seligman, 2011). Life satisfaction represents the perceived difference between current life status and an individual's expectations and aspirations (Campbell, Converse, \& Rodgers, 1976); life satisfaction has been defined as "global evaluation by the person of his or her life" (Pavot, Diener, Colvin, \& Sandvik, 1991, p. 150). It has been repeatedly proven that life satisfaction is associated with personality traits of neuroticism (negatively), extraversion and consciountiouness (Lucas, 2008; Pavot \& Diener, 2011).

\section{Job Satisfaction}

Life satisfaction is a very general evaluative judgment about the quality of one's own life. Diener et al. (1999) therefore subdivided life satisfaction into so-called domains of satisfaction, including satisfaction with work, family, leisure, health, finances, self and one's group. From this perspective, job satisfaction is one such domain.

In contrast to life satisfaction, which reflects an overall view of life, job satisfaction is a more complex construct. Job satisfaction is composed of several factors such as achievement, recognition, the work itself, career prospects, salary status, collegial relationships, institutional climate, physical working conditions etc. (Hagedorn, 2000; Herzberg, 1959; Kristensen, Hannerz, Høgh, \& Borg, 2005). 
Job satisfaction is therefore a multidimensional construct, and considering these factors, it would be expected that job satisfaction is affected primarily by objective working conditions or attitudinal or motivational personality characteristics. However, personality traits also partially predict job satisfaction. Similarly to life satisfaction, job satisfaction is influenced by neuroticism, extraversion and conscientiousness (Judge, Heller, \& Mount, 2002; Bruk-Lee, Khoury, Nixon, Goh, \& Spector, 2009; Hahn, Gottschling, König, \& Spinath, 2016).

\section{Work Engagement}

The concept of work engagement emerged in the framework of burnout research (Maslach, Schaufeli, \& Leiter, 2001). According to Schaufeli, Taris, and Van Rhenen (2008), engaged employees have a sense of energetic and effective connection with their work activities and see themselves as able to effectively handle the demands of their job. Work engagement comprises three components (Schaufeli \& Salanova, 2002): vigor (high levels of energy and mental resilience while working), dedication (a sense of significance, enthusiasm, inspiration, pride, and challenge), and absorption (being fully concentrated and engrossed in one's work). According to meta-analysis byMäkikangas, Feldt, Kinnunen, and Mauno(2013) neuroticism and extraversion were negatively and positively related to work engagement, respectively. Of the other Big Five personality traits, conscientiousness was positively associated with high work engagement levels.

\section{Current Study}

The aim of the study was to examine the role of characteristic adaptations among personality traits, domain satisfaction and overall life satisfaction. Since characteristic adaptations are contextually conditioned, it is necessary to take into consideration the settings in which they manifest themselves. We focused on one of the most important domains in the life of an adult: the work domain.

Previous research has shown associations of personality traits with work engagement (Mäkikangas et al., 2013), job satisfaction (Judge et al., 2002) and life satisfaction (Steel et al., 2008), as well as relationships between work engagement and job satisfaction (Rayton \& Yalabik, 2014) and between job satisfaction and life satisfaction (Li, Fan, \& Zhao, 2015). Li, Wang, Gao, and You (2015) examined the mediating effects of work engagement between proactive personality and job satisfaction, and Zhai, Willis, O'Shea, Zhai, and Yang (2013) studied the mediating role of job satisfaction between the Big Five personality traits and life satisfaction. To our knowledge, no study has investigated the relationships between personality traits, work engagement, job satisfaction and life satisfaction.

Although several authors consider work engagement as an indicator of occupational wellbeing (Mäkikangas et al., 2013) or job satisfaction outcome (Rayton \& Yalabik, 2014), we interpret work engagement as a characteristic adaptation. We begin from the operational definition of work engagement by Christian, Garza, and Slaughter (2011), who emphasized two characteristics of Kahn's (1990) conceptualization of work engagement. First, work engagement concerns more the psychological relationship with performance of work tasks than with attitudes regarding aspects of the organization or job. Second, work engagement concerns selfinvestment of personal resources into work i.e., the physical, emotional and cognitive potential that people apply to their job roles. Our interpretation of work engagement as a characteristic adaptation is further supported by the evidence that work engagement appears to remain relatively stable over the long term, although there are day-to-day fluctuations (state 
work engagement) that are likely context dependent (Bakker \& Leiter, 2010; Christian et al., 2011). Engagement thus varies both between persons and within a person, but this variability is a common characteristic of many psychological constructs, including personality traits, which are also stable over time while exhibiting slight state fluctuations in the short term (Tickle, Heatherton, \& Wittenberg, 2001). We suppose that identified personality correlates of work engagement, the traits of neuroticism, extraversion and conscientiousness, influence work engagement through energy-efficient features (vigor, achievement).

In our study, we assessed whether work engagement and job satisfaction intervene in the relationship between personality traits and life satisfaction in a sample of academic workers. In these assessments, we hypothesized that personality traits would retain their direct influence on both job satisfaction and life satisfaction. Neuroticism, extraversion and conscientiousness, as the most consistent and stable predictors of work engagement, job satisfaction and life satisfaction, were identified within the framework of Big Five personality constructs (Blatný \& Šolcová, 2015; Judge et al., 2002; Mäkikangas et al., 2013). We focused on these three traits in our research. We assumed that neuroticism would reduce work engagement and both directly and indirectly decrease job satisfaction and life satisfaction, while extraversion and conscientiousness would directly influence job satisfaction and life satisfaction and would increase enthusiasm and effective connection with work, thus indirectly promoting job satisfaction and life satisfaction.

\section{Method}

\section{Procedure}

The data were collected using our web-based questionnaire with response validation to en- sure the completeness of the data. To contact the participants, we compiled a list of email addresses of all academic faculty members publicly available from websites of Czech public universities. The respondents were invited to participate in the research via e-mail; the invitation included a brief summary of the research aims and a direct link to the questionnaire. Data collection occurred in the second half of the 2014 fall semester. To protect the anonymity of the respondents, we decided not to ask the exact age of the respondents but rather to select the appropriate age category.

\section{Sample}

Alltogether, more than 20000 academic workers were contacted via e-mail. About $23 \%$ of contacted academics followed the provided link to the survey and started responding. The research sample in our study consisted of 2229 (57.1\% men) participants who finished completing the questionnaire. The basic characteristics of the sample are summarized in Table 1.

\section{Instrument}

The instrument consisted of various measurement scales and questionnaires concerning the respondents' demographic characteristics (age, gender, etc.), employment variables (formal position, type of contract, length of employment, etc.), work content and productivity variables (working hours, proportion of work time dedicated to research/teaching/administration, numbers of publications, grants, and scholarships, etc.), work environment variables, aspects of employee well-being, and personality characteristics.

In this study, we used the following measures:

Short version of the Big Five Inventory (BFI10) (Rammstedt \& John, 2007). This instrument consists of 10 items ( 2 items per dimension, one 
Table 1 Descriptive characteristics of the research sample

\begin{tabular}{ll}
\hline Age & $<25$ years: $0.8 \%$ \\
& $25-29$ years: $14.4 \%$ \\
& $30-39$ years: $40.4 \%$ \\
& $40-49$ years: $17.2 \%$ \\
& $50-59$ years: $13.6 \%$ \\
& $60-69$ years: $9.8 \%$ \\
& $70-79$ years: $3.3 \%$ \\
& $\geq 80$ years: $0.4 \%$ \\
\hline Discipline & Humanities/Social sciences: 42.2 \\
& Natural sciences: $30.3 \%$ \\
& Technical sciences: $22.7 \%$ \\
& Other: $4.8 \%$ \\
\hline Position & PhD student $/$ postdoc: $16.4 \%$ \\
& Lecturer: $4.4 \%$ \\
& Researcher: $9.5 \%$ \\
& Assistant professor: $42.9 \%$ \\
Associate professor: $15.2 \%$ \\
Professor: $7.9 \%$ \\
Other: $3.8 \%$ \\
\hline
\end{tabular}

coded in the positive direction and one in the negative direction of the scale), as well as 1 additional positively directed item for the agreeableness scale. The response format is a five-step scale from 1 = "disagree strongly" to 5 = "agree strongly". Only three dimensions were used in this study - conscientiousness (Spearman-Brown $\rho=0.441)$, neuroticism ( $\rho=$ $0.636)$, and extraversion $(\rho=0.514)$. Although there is a debate concerning the usability of the short version of BFI in different countries (Ludeke \& Larsen, 2017), in the context of the Czech Republic it was verified that the short version is able to reconstruct information about the five personality traits to a high degree (Hřebíčková et al., 2016). Moreover, we decided to use BFI-10 to avoid the time demands of the full-length BFI.

Utrecht Work Engagement Scale short form (Schaufeli, Bakker, \& Salanova, 2006) - This 9item scale uses a response format of a scale from $1=$ "never" to 7 = "all the time/every day". Cronbach's $\alpha$ of the scale is 0.912 . The scale is tended as a three-dimensional measure of vigor, dedication, and absorption. Based on the results of exploratory factor analysis (first eigenvalue to second eigenvalue ratio of 5.82) and in accordance with Sonnentag (2003), we decided to use the total score as a measure of work engagement.

Job Satisfaction Scale - The 4-item job satisfaction short scale from the COPSOQ-II (Kristensen et al., 2005), supplemented by an item focused on the financial aspect, uses a response format of a scale from $1=$ "very unsatisfied" to $4=$ "very satisfied". Cronbach's $\alpha$ of this five-item scale is 0.759 .

Satisfaction with Life Scale (Pavot \& Diener, 1993) - This is a 5-item scale with a response format of a scale from $1=$ "strongly disagree" to $7=$ "strongly agree". Cronbach's $\alpha$ of this scale is 0.893 . 


\section{Statistical Analysis}

The structural model presented in the Results was computed using the lavaan package in $\mathrm{R}$ (Rosseel, 2012) and was estimated using the robust maximum likelihood method (MLM maximum likelihood estimation with robust standard errors and a Satorra-Bentler scaled test statistics). For personality characteristics, we used individual items as indicators. For all remaining latent variables, we used three parcels per variable as indicators to reduce the sampling variability and the amount of model incorrectness (Little, 2013). Individual scale items were distributed into parcels based on their order. The parcels were computed as mean scores for relevant items. We controlled for the influence of age and gender by incorporating them as predictors of each latent variable. We used the marker variable method to set the scale of each latent variable. Due to the large sample size, we report and interpret results only for variables meeting a $1 \%$ threshold for significance. When describing effect sizes in case of correlations we stick to the guidelines suggested by Gignac and Szodorai (2016).

\section{Results}

In Table 2, we summarize descriptive univariate and bivariate statistics for the variables used in the subsequent analyses. The presented results clearly show that general life satisfaction is notably related to personality characteristics (to extraversion on small level and neuroticism on medium level) and to jobrelated characteristics on large level (work engagement and job satisfaction).

Based on theoretical considerations we postulate a structural model in which personality characteristics predict work engagement, which consequently predicts job satisfaction and, ultimately, overall life satisfaction. We also hypothesize that personality traits directly influence both job satisfaction and life satisfaction and, therefore, the appropriate direct paths were incorporated into the model (see Figure 1). The model overall shows very good fit $\left(\chi^{2}=659.4\right.$; $d f=94 ; p<0.01 ; \mathrm{RMSEA}=0.055 ; 90 \%$ CI $[0.051$

Table 2 Descriptive statistics of basic demographic, personality-related and job-related variables and their correlations

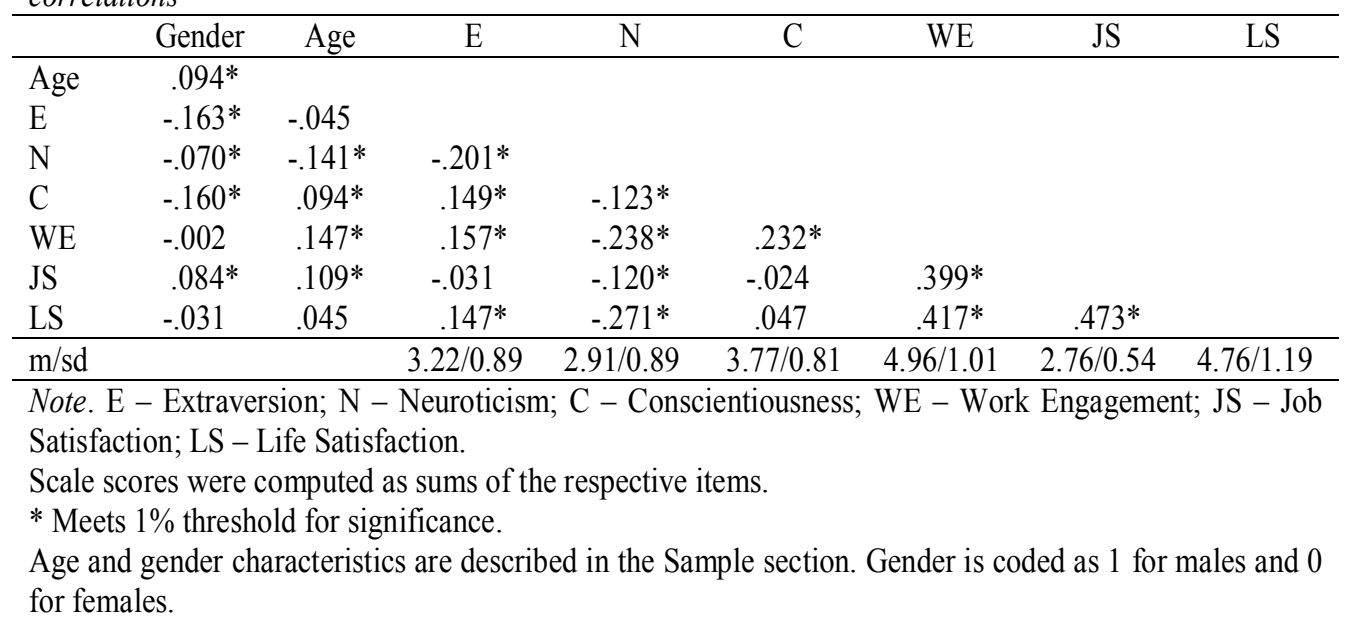




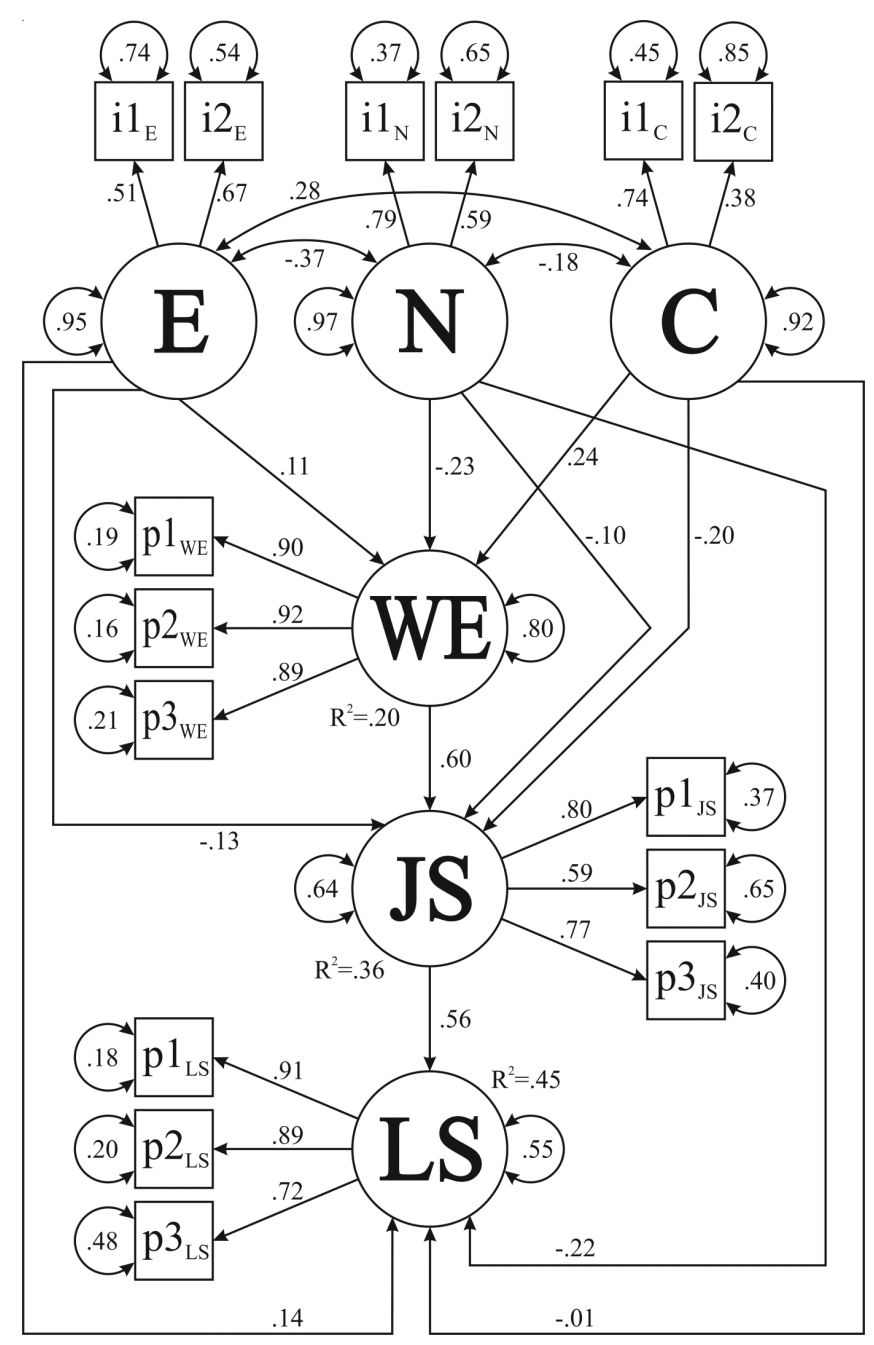

Note. E - Extraversion; N - Neuroticism; C - Conscientiousness; WE - Work Engagement; JS - Job Satisfaction; LS - Life Satisfaction. All presented estimates are in the standardized form. With the exception of the regression coefficient between $\mathrm{C}$ and LS, all relations are significant at the $1 \%$ level. For the sake of clarity, age and gender relations are not depicted in the schematic: $\mathrm{E}$ $\sim$ gender $=-.21^{* *} ; \mathrm{N} \sim$ gender $=-.07^{* *} ; \mathrm{C} \sim$ gender $=-.22 * * ; \mathrm{WE} \sim$ gender $=.05 ; \mathrm{JS} \sim$ gender $=.00$; $\mathrm{LS} \sim$ gender $=-.07^{* *} ; \mathrm{E} \sim$ age $=-.01 ; \mathrm{N} \sim$ age $=-.16^{* *} ; \mathrm{C} \sim \operatorname{age}=.18^{* *} ; \mathrm{WE} \sim$ age $=.07 * * ; \mathrm{JS} \sim$ age $=.06^{* *} ; \mathrm{LS} \sim$ age $=-.06^{* *}$ (gender is coded as 1 for males and 0 for females; ${ }^{* *}$ meets $1 \%$ threshold for significance).

Figure 1 Structural model - Personality characteristics as predictors of work engagement, job satisfaction and life satisfaction 
to 0.059]; $\mathrm{SRMR}=0.037$; $\mathrm{CFI}=0.956$ ). Even though the chi-square ratio does not favor the model tested, other indices strongly support the fit of the model (Hooper, Coughlan, \& Mullen, 2008).

As shown in Figure 1, close relations were observed between work engagement and job satisfaction, as well as between job satisfaction and general life satisfaction. Personality characteristics are directly related to work engagement as well as to job and life satisfaction. Relationships were found between neuroticism and work engagement $(\beta=-.23)$ and neuroticism and life satisfaction $(\beta=-.22)$. Interestingly enough, in case of conscientiousness, significant relationships were found only for work re- lated characteristics. Conscientiousness positively influence work engagement $(\beta=.24)$, while its direct influence on job satisfaction is negative $(\beta=-.20)$. Relationships between extraversion and the other constructs are relatively small but still significant. To produce a clear profile of the influence of personality characteristics on job and life satisfaction, we summarize their direct and indirect effects in Table 3.

The strongest predictor of life satisfaction is neuroticism, with a total standardized effect of -.36; this effect manifested through one direct and two indirect pathways. One indirect way involves work engagement and job satisfaction, and the other indirect pathway involves job satisfaction but not work engagement. Overall,

Table 3 Direct and indirect relations of personality characteristics with job satisfaction and life satisfaction

\begin{tabular}{llc}
\hline Relation & Effect type & Standardized estimate \\
\hline $\mathrm{E} \rightarrow \mathrm{JS}$ & Direct & $-.13^{*}$ \\
& Indirect & $.07^{*}$ \\
& Total & -.07 \\
\hline $\mathrm{E} \rightarrow \mathrm{LS}$ & Direct & $.15^{*}$ \\
& Indirect $1(\mathrm{E} \rightarrow \mathrm{WE} \rightarrow \mathrm{JS} \rightarrow \mathrm{LS})$ & $.04^{*}$ \\
& Indirect $2(\mathrm{E} \rightarrow \mathrm{JS} \rightarrow \mathrm{LS})$ & $-.08^{*}$ \\
& Total & $.11^{*}$ \\
\hline $\mathrm{N} \rightarrow \mathrm{JS}$ & Direct & $-.10^{*}$ \\
& Indirect & $-.14^{*}$ \\
& Total & $-.24^{*}$ \\
\hline $\mathrm{N} \rightarrow \mathrm{LS}$ & Direct & $-.22^{*}$ \\
& Indirect $1(\mathrm{~N} \rightarrow \mathrm{WE} \rightarrow \mathrm{JS} \rightarrow \mathrm{LS})$ & $-.08^{*}$ \\
& Indirect $2(\mathrm{~N} \rightarrow \mathrm{JS} \rightarrow \mathrm{LS})$ & $-.05^{*}$ \\
& Total & $-.36^{*}$ \\
\hline $\mathrm{C} \rightarrow \mathrm{JS}$ & Direct & $-.20^{*}$ \\
& Indirect & $.14^{*}$ \\
& Total & -.05 \\
\hline $\mathrm{C} \rightarrow \mathrm{LS}$ & Direct & -.01 \\
& Indirect $1(\mathrm{C} \rightarrow \mathrm{WE} \rightarrow \mathrm{JS} \rightarrow \mathrm{LS})$ & $.08^{*}$ \\
& Indirect $2(\mathrm{C} \rightarrow \mathrm{JS} \rightarrow \mathrm{LS})$ & $-.11^{*}$ \\
& Total & -.04 \\
\hline
\end{tabular}

Note. E - Extraversion; N - Neuroticism; C - Conscientiousness; WE - Work Engagement; JS - Job Satisfaction; LS - Life Satisfaction.

* Meets $1 \%$ threshold for significance. 
neuroticism showed a consistent negative effect on life satisfaction. To fully clarify the effect of extraversion on life satisfaction, we focused on the relationship between extraversion and job satisfaction. Even though its indirect effect on job satisfaction through work engagement was positive, its direct effect was negative. Therefore, extraversion showed both negative $(\mathrm{E} \rightarrow \mathrm{JS} \rightarrow \mathrm{LS})$ and positive $(\mathrm{E} \rightarrow \mathrm{WE} \rightarrow \mathrm{JS}$ $\rightarrow$ LS) indirect effects on life satisfaction. These indirect effects were accompanied by a positive direct effect of extraversion on life satisfaction. The indirect influences of conscientiousness on life satisfaction were stronger than those of extraversion, but their pattern was similar (positive effect when involving work engagement and negative effect when not involving work engagement). In contrast to extraversion, conscientiousness did not show a direct effect on life satisfaction, and the total effect of conscientiousness on life satisfaction was insignificant.

\section{Discussion}

Our main objective was to evaluate the influences of the personality traits of neuroticism, extraversion and conscientiousness on life satisfaction through work engagement and job satisfaction. Additionally, we monitored the direct influences of these personality traits on job satisfaction and life satisfaction. The results regarding the influences of these personality traits on life satisfaction and job satisfaction through work engagement were consistent with our hypotheses and are consistent with previous findings. Extraversion, conscientiousness and emotional stability showed a positive effect on work engagement (Inceoglu \& Warr, 2011; Pocnet et al., 2015); as expected, high work engagement in turn positively affects job satisfaction (Karanika-Murray, Duncan, Pontes, \& Griffiths, 2015), and job satisfaction is associated with life satisfaction (Newman, Nielsen,
Smyth, \& Hooke, 2015). Furthermore, the indirect influences of all three personality traits on life satisfaction were significant.

Our assumption that personality traits directly affect life satisfaction was also partially confirmed. While the direct influences of extraversion (positive) and neuroticism (negative) on life satisfaction were significant, the influence of conscientiousness on life satisfaction was not confirmed. One explanation for this result may be that our sample includes predominantly people with above-average levels of conscientiousness. This distribution favoring the upper portion of the conscientiousness range may not adequately distinguish the effect of conscientiousness on life satisfaction. Another explanation may be that conscientiousness affects life satisfaction indirectly through either work engagement or job satisfaction. Given that conscientiousness includes personal characteristics associated with performance, competencies, self-discipline and responsibility, this trait influences overall life satisfaction primarily through the exercise of the professional role, for which these characteristics are important.

Regarding the influence of personality traits on job satisfaction, we found that while the influence of neuroticism was significantly negative as expected, the influences of extraversion and conscientiousness were ambiguous. In addition to the positive effects of both traits on job satisfaction through work engagement, weak negative direct influences of both traits on job satisfaction were observed. Although this finding of a negative effect of conscientiousness on job satisfaction is uncommon, the meta-analysis by Judge et al. (2002) revealed a negative correlation between conscientiousness and job satisfaction. In a previous study (Zábrodská et al., 2016), we explored various aspects of job satisfaction in the same sample (i.e., using scale items) - satisfaction with the job as a whole (everything taken into consideration), physical working conditions, use of abili- 
ties, career prospects and pay. While satisfaction with the job overall and with the working conditions was reported by more than $80 \%$ of respondents, only $2 / 3$ of academic faculty members were satisfied with the use of their own abilities and with their career prospects, and less than half were satisfied with their salary. It is therefore possible that these aspects reduce job satisfaction in individuals with high conscientiousness because they are performanceoriented, ambitious, have a sense of competence and generally focus on success and on achieving their goals, which may exceed the potential of the organization. Experience of inner satisfaction is certainly important, but external factors such as the prospect of a promotion or a financial reward are important as well (Bandura, 1999; Seligman, 2011).

The observed negative influence of extraversion on job satisfaction can be explained according to the concept of proactive personality, in which dispositional characteristics contribute to proactive behavior (Wu, Parker, \& Bindl, 2013). In addition to socio-cognitive (selfefficacy) and affective traits (positive and negative affectivity), extraversion is considered to be a constituent of proactive personality, especially in the facets of assertiveness and activity. In our research, we used the short version of the BFI, which does not measure facets. However, as shown in a study by Rammstedt and John (2007), the dimension of extraversion in BFI-10 correlates with all NEO-PI-R facets. Additionally, in the aforementioned study, extraversion according to BFI-10 most closely correlated with the facet of assertiveness. According to $\mathrm{Wu}$ et al. (2013), proactive behavior is particularly suitable for complex and uncertain environments, as it enables people to control a situation in advance and act in accordance with their own initiative, without the need for supervision by others. In a fairly structured academic environment, such behavior may not be beneficial and may lead to a feeling of wasted poten- tial. Conversely, characteristics associated with introversion, preference for working alone or leaving leadership to others may be advantageous in an academic environment.

Of all three studied traits, neuroticism has the strongest and most consistent negative effect on life satisfaction. Given that the basis of neuroticism is negative emotionality, it is plausible that negative emotions systematically reduce life satisfaction, job satisfaction and work enthusiasm. The effects of extraversion and conscientiousness on life satisfaction are similar in that both show negative influences on life satisfaction through job satisfaction but positive influences on life satisfaction through work engagement. In contrast to neuroticism, extraversion and conscientiousness are rather complex traits (McCrae \& Costa, 1999) that include a variety of characteristics. Further research is needed to determine whether different facets have distinct effects on job satisfaction.

\section{Conclusion}

Of all three studied traits, neuroticism has the strongest and most consistent negative effect on life satisfaction, and this effect was manifested both directly and indirectly - through job satisfaction alone or through work engagement and job satisfaction. Given that the basis of neuroticism is negative emotionality, it is plausible that negative emotions systematically reduce life satisfaction, job satisfaction and work enthusiasm. The effects of extraversion and conscientiousness on life satisfaction show a similar pattern with the exception that conscientiousness has no direct effect on life satisfaction and the overall effect of conscientiousness is insignificant. The effects of extraversion and conscientiousness on life satisfaction are similar in that both show negative influences on life satisfaction through job satisfaction but positive influences on life satisfaction through work engagement. In contrast to neuroticism, extra- 
version and conscientiousness are rather complex traits (Costa \& McCrae, 1992; DeYoung, Quilty, \& Peterson, 2007) that include a variety of characteristics. Further research is needed to determine whether different facets have distinct effects on job satisfaction.

\section{Limitations}

There are several limitations requiring to be mentioned. First, the study design was crosssectional. Thus, causality (from Big Five personality traits to work engagement, job satisfaction and life satisfaction) cannot be inferred. Moreover, some recent longitudinal studies in this area have also shown that reverse causality is a distinct possibility. For example, Rayton and Yalabik (2014) have found negative effect of work engagement on job satisfaction. Future longitudinal work, which is able to better address the direction of these complex associations, will likely further inform this issue.

Another limitation of the study arises from the use of an abbreviated versions of questionnaires, in particular of the personality questionnaire BFI-10. We chose these shortened versions to reduce the total time required to complete the set of questionnaires with the aim of increasing the response rate and indirectly supporting the representativeness of the final sample. Although less information regarding the structure of personality traits was obtained, we believe that the abbreviated version of the BFI-10 allows for adequate testing of the postulated hypotheses, supported by a study by the authors of the method (Rammstedt \& John, 2007), as well as by a subsequent verification of the method in a corresponding national context (Hřebíčková et al., 2016).

\section{References}

Bakker, A. B., \& Leiter, M. P. (2010). Where to go from here: Integration and future research on work engagement. In A. B. Bakker, \& M. P. Leiter (Eds.), A Handbook of essential theory and research (pp. 181-196). Hove, NY: Psychology Press.

Bandura, A. (1999). Social cognitive theory of personality. In D. Cervone, \& Y. Shoda (Eds.), The coherence of personality (pp. 185-241). New York: The Guilford Press.

Blatný, M., \& Šolcová, I. (2015). Well-being. In M. Blatný (Ed.), Personality and well-being across the life-span (pp. 20-59). London: Palgrave Macmillan.

Bruk-Lee, V., Khoury, H. A., Nixon, A. E., Goh, A., \& Spector, P. E. (2009). Replicating and extending past personality/job satisfaction meta-analyses. Human Performance, 22, 156-189. doi: 10.1080/ 08959280902743709.

Campbell, A., Converse, P. E., \& Rodgers, W. L. (1976). The quality of American life: Perceptions, evaluations, and satisfactions. New York: Russell Sage Foundation.

Cellar, D. F., Yorke, C. M., Nelson, Z. C., \& Carroll, K. A. (2004). Relationships between five factor personality variables, workplace accidents, and self-efficacy. Psychological Reports, 94, 1437-1441. doi: 10.2466/pr0.94.3c.1437-1441.

Christian, M. S., Garza, A. S., \& Slaughter, J. E. (2011). Work engagement: A quantitative review and test of its relations with task and contextual performance. Personnel Psychology, 64, 89-136. doi: 10.1111/ j.1744-6570.2010.01203.x.

Costa, P. T., \& McCrae, R. R. (1992). Revised NEO Personality Inventory (NEO PI-R) and NEO Five Factor Inventory: Professional manual. Odessa, FL: Psychological Assessment Resources.

DeYoung, C. G., Quilty, L. C., \& Peterson, J. B. (2007). Between facets and domains: 10 aspects of the Big Five. Journal of Personality and Social Psychology, 93, 880-896. doi: 10.1037/0022-3514.93.5.880.

Diener, E. (2000). Subjective well-being. The science of happiness and a proposal for a national index. American Psychologist, 55, 34-43. doi: 10.1037/ 0003-066X.55.1.34.

Diener, E., Suh, E. M., Lucas, R. E., \& Smith, H. L. (1999). Subjective well-being: Three decades of progress. Psychological Bulletin, 125, 276-302. doi: 10.1037/0033-2909.125.2.276.

Gignac, G. E., \& Szodorai, E. T. (2016). Effect size guidelines for individual differences researchers. Personality and Individual Differences, 102, 74-78.

Hagedorn, L. S. (2000). Conceptualizing faculty job satisfaction: Components, theories, and outcomes. New Directions for Institutional Research, 105, 520. doi: 10.1002/ir.10501.

Hahn, E., Gottschling, J., König, C. J., \& Spinath, F. M. (2016). The heritability of job satisfaction reconsidered: Only unique environmental influences 
beyond personality. Journal of Business and Psychology, 31, 217-231. doi: 10.1007/s10869-0159413-x.

Herzberg, F. (1959). The motivation to work. New York: Wiley.

Hooper, D., Coughlan, J., \& Mullen, M. R. (2008). Structural equation modelling: Guidelines for determining model fit. Electronic Journal of Business Research Methods, 6(1), 53-60. https://doi.org/ 10.1037/1082-989X.12.1.58.

Hřebíčková, M., Jelínek, M., Blatný, M., Brom, C., Burešová, I., Graf, S., . . . \& Zábrodská, K. (2016). Big Five Inventory: Základní psychometrické charakteristiky české verze BFI-44 a BFI-10 [Big Five Inventory: Basic psychometric characteristics of Czech version of BFI-44 and BFI-10]. Československá Psychologie, 60(6), 567-583.

Inceoglu, I., \& Warr, P. (2011). Personality and job engagement. Journal of Personnel Psychology, 10, 177-181. doi: 10.1027/1866-5888/a000045.

Judge, T. A., Heller, D., \& Mount, M. K. (2002). Fivefactor model of personality and job satisfaction: A meta-analysis. Journal of Applied Psychology, 87, 530-541. doi: 10.1037/0021-9010.87.3.530.

Kahn, W. A. (1990). Psychological conditions of personal engagement and disengagement at work. Academy of Management Journal, 33, 692-724. doi: $10.2307 / 256287$.

Karanika-Murray, M., Duncan, N., Pontes, H. M., \& Griffiths, M. D. (2015). Organizational identification, work engagement, and job satisfaction. Journal of Managerial Psychology, 30, 1019-1033. doi: 10.1108/JMP-11-2013-0359.

Kristensen, T. S, Hanez, H., Høgh, A., \& Borg, V. (2005). The Copenhagen Psychosocial Questionnaire - A tool for the assessment and improvement of the psychosocial work environment. Scandinavian Journal of Work, Environment and Health, 31, 438-449. doi: 10.5271/sjweh.948.

Lent, R. W., Singley, D., Sheu, H., Gainor, K. A., Brenner, B. R., Treistman, D., \& Ades, L. (2005). Social cognitive predictors of domain and life satisfaction: Exploring the theoretical precursors of subjective well-being. Journal of Counseling Psychology, 52, 429-442. doi: 10.1037/0022-0167.52.3. 429.

Li, M., Wang, Z., Gao, J., You, X. (2015). Proactive personality and job satisfaction: The mediating effects of self-efficacy and work engagement in teachers. Current Psychology, 515-523. doi: 10.1007/ s12144-015-9383-1.

Li, Y., Fan, J., \& Zhao, S. (2015). Organizational identification as a double-edged sword. Journal of Personnel Psychology, 14, 182-191. doi: 10.1027/18665888/a000133.
Little, T. D. (2013). Longitudinal structural equation modelling. New York: The Guilford Press.

Lucas, R. E. (2008). Personality and subjective wellbeing. In M. Eid, \& R. J. Larsen (Eds.), The science of subjective well-being (pp. 171-194). New York: The Guilford Press.

Ludeke, S. G., \& Larsen, E. G. (2017). Problems with the Big Five assessment in the World Values Survey. Personality and Individual Differences, 112, 103105 .

Lyubomirsky, S., Sheldon, K. M., \& Schkade, D. (2005). Pursuing happiness: The architecture of sustainable change. Review of General Psychology, 9, 111-131. doi: 10.1037/1089-2680.9.2.111.

Mäkikangas, A., Feldt, T., Kinnunen, U., \& Mauno, S. (2013). Does personality matter? A review of individual differences in occupational well-being. In A. B. Bakker (Ed.), Advances in positive organizational psychology (pp. 107-143). Emerald Group Publishing Limited.

Maslach, C., Schaufeli, W. B., \& Leiter, M. P. (2001). Job burnout. Annual Review of Psychology, 52, $397-$ 422. doi: 10.1146/annurev.psych.52.1.397.

McAdams, D. P., \& Pals, J. L. (2006). A new Big Five: Fundamental principles for an integrative science of personality. American Psychologist, 61, 204-217. doi: 10.1037/0003-066X.61.3.204.

McCrae, R. R., \& Costa, P. T. (1999). A five-factor theory of personality. In L. A. Pervin, \& O. P. John (Eds.), Handbook of personality: Theory and research (2nd ed., pp. 139-153). New York: The Guilford Press.

Newman, A., Nielsen, I., Smyth, R., \& Hooke, A. (2015). Examining the relationship between workplace support and life satisfaction: The mediating role of job satisfaction. Social Indicators Research, 120, 769-781. doi: 10.1007/s11205-014$0613-\mathrm{y}$.

Ozer, D. J., \& Benet-Martínez, V. (2006). Personality and the prediction of consequential outcomes. Annual Review of Psychology, 57, 401-42. doi: 10.1146/annurev.psych.57.102904.190127.

Pavot, W., \& Diener, E. (1993). Review of the Satisfaction with Life Scale. Psychological As sessment, 5, 164-172. doi: 10.1037/10403590.5.2.164.

Pavot, W., \& Diener, E. (2011). Personality and happiness: Predicting the experience of subjective wellbeing. In T. Chamorro-Premuzic, S. von Stumm, \& A. Furnham (Eds.), The Wiley-Blackwell handbook of individual differences (pp. 699-717). Oxford: Blackwell Publishing Ltd.

Pavot, W., Diener, E., Colvin, C. R., \& Sandvik, E. (1991). Further validation of the Satisfaction with Life Scale: Evidence for the cross-method conver- 
gence of well-being measures. Journal of Personality Assessment, 57, 149-161. doi: 10.1207/ s15327752jpa5701_17.

Pocnet, C., Antonietti, J., Massoudi, K., Györkös, C., Becker, J., de Bruin, G. P., \& Rossier, J. (2015). Influence of individual characteristics on work engagement and job stress in a sample of national and foreign workers in Switzerland. Swiss Journal of Psychology, 74, 17-27. doi: 10.1024/1421-0185/ a000146.

Rammstedt, B., \& John, O. P. (2007). Measuring personality in one minute or less: A 10-item short version of the Big Five Inventory in English and German. Journal of Research in Personality, 41, 203 212. doi: $10.1016 /$ j.jrp.2006.02.001.

Rayton, B. A., \& Yalabik, Z. Y. (2014). Work engagement, psychological contract breach and job satisfaction. International Journal of Human Resource Management, 25, 2382-2400. doi: 10.1080/ 09585192.2013 .876440 .

Rosseel, Y. (2012). Lavaan: An R package for structural equation modeling. Journal of Statistical Software, 48, 1-36.

Ryff, C. D. (2014). Psychological well-being revisited: Advances in the science and practice of eudaimonia. Psychotherapy and Psychosomatics, 83, 10-28. doi: 10.1159/000353263.

Schaufeli, W. B., Bakker, A. B., \& Salanova, M. (2006). The measurement of work engagement with a short questionnaire: A cross-national study. Educational and Psychological Measurement, 66, 701-716. doi: 10.1177/0013164405282471.

Schaufeli, W. B., Salanova, M., González-Romá, V., \& Bakker, A. B. (2002). The measurement of engagement and burnout: A two-sample confirmatory factor analytic approach. Journal of Happiness Studies, 3(3), 71-92. doi: 10.1023/A: 1015630930326.

Schaufeli, W. B., Taris, T. W., \& Van Rhenen, W. (2008). Workaholism, burnout, and work engagement: Three of a kind or three different kinds of employee well- being? Applied Psychology, 57, 173-203. doi: 10 $1111 /$ j.1464-0597.2007.00285.x.

Seligman, M. E. P. (2011). Flourish: A visionary new understanding of happiness and well-being. New York: Free Press.

Sonnentag, S. (2003). Recovery, work engagement, and proactive behavior: A new look at the interface between nonwork and work. Journal of Applied Psychology, 88, 518-528. doi: 10.1037/0021-9010. 88.3.518.

Steel, P., Schmidt, J., \& Shultz, J. (2008). Refining the relationship between personality and subjective wellbeing. Psychological Bulletin, 134, 138-161. doi: 10.1037/0033-2909.134.1.138.

Tickle, J. J., Heatherton, T. F., \& Wittenberg, L. G. (2001). Can personality change? In W. J. Livesley (Ed.), Handbook of personality disorders: Theory, research, and treatment (pp. 242-258). New York: The Guilford Press.

Watson, D., Suls, J., \& Haig, J. (2002). Global selfesteem in relation to structural models of personality and affectivity. Journal of Personality and Social Psychology, 83, 185-197. doi: 10.1037/00223514.83.1.185.

Wu, C.-H., Parker, S. K., \& Bindl, U. K. (2013). Who is proactive and why? Unpacking individual differences in employee proactivity. In A. B. Bakker (Ed.), Advances in positive organizational psychology (pp. 261-280). Croydon: Emerald Group Publishing Limited.

Zábrodská, K., Mudrák, J., Květon, P., Blatný, M., Machovcová, K., \& Šolcová, I. (2016). Keeping marketisation at bay: The quality of academic worklife in Czech universities. Czech Sociological Review, 52, 347-374. doi: 10.13060/00380288. 2016.52.3.262.

Zhai, Q., Willis, M., O'Shea, B., Zhai, Y., \& Yang, Y. (2013). Big five personality traits, job satisfaction and subjective wellbeing in China. International Journal of Psychology 48, 1099-1108. doi: 10.1080/ 00207594.2012 .732700 . 